\title{
APSA Awards Presented at the 2016 Annual Meeting
}

$\mathrm{R}$ ecognizing excellence in the profession is one of the most important roles of the American Political Science Association. Through the service of member committees who review nominations, APSA presents awards for the best dissertations, papers and articles, and books in the various subfields of the discipline as well as for career achievement in research, teaching and service to the discipline. The 2016 APSA Awards were presented at the Annual Meeting in Philadelphia on August 31.

\section{Career Awards}

\section{FRANK J. GOODNOW AWARD}

The Frank Johnson Goodnow Award was established by the APSA Council in 1996 to honor service to the community of teachers, researchers, and public servants who work in the many fields of politics. Frank J. Goodnow, the first president of the American Political Science Association, a pioneer in the development of judicial politics, and former president of Johns Hopkins University, is an exemplar of the public service and volunteerism that this award represents.

Award Committee: Anne Schneider, Arizona State University, Chair; Richard Johnston, University of British Columbia; Tom Remington, Emory University

\section{Recipient: Virginia Sapiro, Boston University}

Citation: Our honoree this year is Virginia Sapiro, professor of political science, Dean of the College and Graduate School of Arts and Sciences at Boston University. She has served the profession with her scholarship, her intellectual contributions, and her service to literally dozens of different aspects of the American Political Science Association.

Perhaps most notable is her contribution to opening the profession and the Association to women and to the subfield of women and politics. In the 1970s, when Sapiro finished her degree and began what became an outstanding career, the decision to focus on women in politics was controversial. This was not an established field of study. Who would want to spend their time studying women in politics (some still thought this an oxymoron) where the possibilities for publication and recognition for one's work were slim? But it is to Sapiro, and others like her, who took the risk of creating excellence in a new field, that we owe such a debt of gratitude for the continuing and difficult efforts to ensure equal opportunity for women and minority scholars.

Creating a path for women in the profession requires not just advocacy, but scholarship that meets the standards of the discipline and contributes to our understanding of politics and democracy. Sapiro exemplifies that standard. In 1993 she won the Victoria Schuck Award for best book published on women and politics for her book A Vindication of Political Virtue. Her work has had a profound impact on the direction of the field, beginning with her 1981 APSR article, "Are Interests Interesting," that made a sophisticated argument for the representation of women by women. Her 1986 PSQ article on "The Gender Basis of American Social Policy" and her 1993 AJPS article with Pamela Conover on "Gender, Feminist Consciousness, and War" have been highly influential as has her text, Women in American Society: An Introduction to Women's Studies.

Advocacy, organizational skills, and leadership also are required, however, to build a subfield in the discipline. Sapiro excels in these as well. She played an important role in getting the Women's Caucus for Political Science started and sustained. The Caucus became the place where women could attend a meeting of the APSA (or the Western, Southern, Midwest) meetings and feel like they "belonged" even as they sat in panels day after day where all the presenters were male. She founded the Organized Section on Women and Politics Research for APSA, an investment of time and energy that has been critical for the development of scholarly work on women and politics.

The development of a subfield in a discipline requires journals that will set high standards, mentor young researchers, and bring visibility to the field and its contribution to the broader study of politics. Sapiro served on the search committees for an editor or editorial team for the journals, Women and Politics, and then Politics and Gender, five times from 1983 to 2007 .

She has served the profession more broadly, also, as secretary of the APSA, vice president of the Association, and chair of the 1998 Annual Meeting. She has served on the editorial board of eight different political science journals. She has been the director and Principal Investigator of the American National Election Studies and on its Board of Overseers. Her work on the ANES is especially notable, as it came during a time when the National Election Studies was having problems. The ANES for years has been a staple for students of voting behavior. In the late 9os, the ANES was being challenged, as newer and cheaper data collection modes were undermining its claim to distinctive value, and the NSF was questioning the costs. In 1998, Sapiro stepped into the breach as acting PI and was critical to keeping the ship afloat.

As one of her nominators said, "In short, this is a woman who time and again has plugged in where the profession needed her, helping to found and sustain many of the institutions in the profession that have furthered women's interests and many of the institutions that have furthered the interests of all." The Goodnow Award must have had her in mind, and we are delighted to award it to her.

\section{JOHN GAUS AWARD}

The John Gaus Award and Lectureship honors the recipient's lifetime of exemplary scholarship in the joint tradition of political science and public administration and, more generally, recognizes and encourages scholarship in public administration.

Award Committee: Lael Keiser, University of Missouri, Chair; Frances Berry, Florida State University; Dan Carpenter, Harvard University

\section{Recipient: Rosemary O’Leary,}

University of Kansas

Citation: We are proud to confer the 2016 John Gaus award upon Rosemary O'Leary . O'Leary is the Edwin O. Stene Distinguished Professor at the School of Public Affairs, University of Kansas and is a Fellow of the National Academy of Public Administration. 
O’Leary has made outstanding contributions to our knowledge about environmental law and policy, collaboration, and managing dissent within public organizations. She has authored eleven books and more than 125 articles and book chapters. Her accomplishments have been recognized through several prestigious awards such as the American Society for Public Administration's Dwight Waldo Award (2014) and the Charles H. Levine Memorial Award (2007).

O'Leary is a leader in her field. As noted in her nomination letter, "In almost all of her scholarship, she works with others-collaborating, co-authoring, convening, and engaging others in the best of academic public administration, political science, and policy studies." O'Leary's scholarly achievements epitomize the lifetime of exemplary scholarship envisaged by APSA for this award.

\section{ITHIEL DE SOLA POOL AWARD}

The Ithiel de Sola Pool Award and Lectureship was established in 1995 by the Association to honor the memory and contributions of Ithiel de Sola Pool. The award honors a scholar whose research explores a broad range of fields pursued by Ithiel de Sola Pool including political theory, political behavior, political communication, science and technology policy, and international affairs.

Award Committee: Danielle Vinson, Furman University, Chair; Matt Baum, Harvard Kennedy School; Andy Gelman, Columbia University

\section{Recipient: Robert Huckfeldt, University of California, Davis}

Citation:Through his broad body of work spanning four decades and 70 publications in outlets ranging from the American Political Science Review, American Journal of Political Science, and Journal on Politics, to Political Analysis, Robert Huckfeldt has left an indelible footprint on political science, particularly the fields of political behavior, public opinion, and communication, that reflects the spirit and legacy of Ithiel de Sola Pool. From broad questions, such as how people make political decisions when they have little information, to more focused ones including the circumstances under which we accurately assess others' political views, Huckfeldt has reminded us of the need to consider context, as well as the importance of people's networks and the social structures in which they live and work, to understand their political behavior.
HUBERT H. HUMPHREY AWARD

The Hubert H. Humphrey Award is awarded annually in recognition of notable public service by a political scientist.

Award Committee: Raphael Sonenshein, California State University, Los Angeles, Chair; Anthony King, University of Essex; Les Lenkowsky, Indiana University

\section{Recipient: Edwin Dorn, University of Texas} at Austin

Citation: Edwin C. Dorn graduated Phi Beta Kappa from the University of Texas at Austin. He received his MA degree from Indiana University, and completed his $\mathrm{PhD}$ degree in political science at Yale University.

Dorn went to Washington in 1977 to join the Carter Administration. He served as an appointee in the US Department of Health, Education, and Welfare and in the US Department of Education. From 1981 to 1990, he served as Deputy Director for Research at the Joint Center for Political and Economic Studies. He created the Joint Center's military affairs program.

In 1993, President Bill Clinton appointed Dorn and he was confirmed by US Senate to serve as an Assistant Secretary of Defense. The following year, he was appointed and confirmed as the Under Secretary of Defense for Personnel and Readiness. He was responsible for policies governing recruitment, pay and benefits for DoD's total force of more than three million military personnel and civilians. His innovations included new systems to monitor military readiness and new mechanisms to coordinate legislative proposals.

In 1997, Dorn was named Dean of the LBJ School where he served with great distinction until 2004. Dorn is the author of Rules and Racial Equality (Yale University Press) and Who Defends America (Joint Center Press). He was an advisor to two public television series: Congress: We The People and Eyes on the Prize: America's Civil Rights Years, and a commentator on National Public Radio's “Tell Me More," hosted by Michel Martin.

Edwin Dorn has made immense contributions to public policy as well as to the political science and public policy university communities. He has demonstrated how boundaries between the academy and government can be bridged. For his extraordinary achievements and outstanding leadership, he is truly deserving of the Hubert H. Humphrey Award.

DISTINGUISHED TEACHING AWARD The APSA Distinguished Teaching Award honors the outstanding contribution to undergraduate and graduate teaching of political science at two- and four-year institutions. The contribution may span several years or an entire career, or it may be a single project of exceptional impact.

Award Committee: Sherri Wallace, University of Louisville, Chair; Jacqui Briggs, University of Lincoln; Richard Holtzman, Bryant University

Recipient: Dewey Clayton, University of Louisville

Citation: Dewey M. Clayton, professor in the department of political science at the University of Louisville, is the recipient of the 2016 American Political Science Association Distinguished Teaching Award. During his long and illustrious career, Clayton has proved to be a dedicated, inspirational and innovative instructor and mentor, positively impacting the lives of his students, even long after they graduate. He embraces a range of pedagogical techniques, including face-toface instruction, distance learning, and community-wide active learning projects. His award-winning "Political Discourse" class, which combines public speaking with political discourse from the civil rights movement, exemplifies his innovative efforts to extend teaching beyond the classroom and into the community. This recognition of Clayton for his contributions to political science teaching is a well-deserved.

\section{CAREY MCWILLIAMS AWARD}

The Carey McWilliams Award is given annually to honor a major journalistic contribution to our understanding of politics.

Award Committee: Steve Livington, George Washington University; Andrew Chadwick, Royal Holloway, University of London; Josh Tucker, New York University

Recipient: Alan Rusbridger, The Guardian Citation: Alan Rusbridger is the former editor-in-chief of the Guardian and now Principal of Lady Margaret Hall, Oxford. He is credited with expanding the global reach of The Guardian and for managing The Guardian's coverage of what until recently were the largest leaks of documents in history: the 2010 Wikileaks stories and the 2013 Snowden files. In Britain The Guardian was, for many months, the only paper to write about WikiLeaks or to use any of the documents they were unearthing. As early as 2007 it reported on documents which revealed that former Kenyan president Daniel Arap Moi had been siphoning off hundreds of millions of pounds and hiding them away in 
foreign bank accounts. This was well before the release of documents by Chelsea Manning. In June 2013, Edward Snowden, an NSA security analyst; Glenn Greenwald, a legal blogger; and Laura Poitras, a filmmaker collaborated to release the National Security Agency files in The Guardian. The Guardian won a Pulitzer Prize for its coverage of the Snowden documents. In his stewardship of the Guardian through the Wikileaks and Snowden episodes and his farsighted push to move the world's oldest newspaper into the digital age, Rusbridger has made an enormous contribution to the public's understanding of state-media relations and political journalism in the digital era.

\section{Book Awards}

\section{RALPH J. BUNCHE AWARD}

The Ralph Bunche Award is given annually for the best scholarly work in political science that explores the phenomenon of ethnic and cultural pluralism.

Award Committee: Christina Greer, Fordham University, Chair; Kanchan Chandra, New York University; Marc Helbling, Social Science Research Center WZB

Recipients: Marisa Abrajano, University of California, San Diego and Zoltan Hajnal, University of California, San Diego

Title: White Backlash:Immigration, Race, and American Politics, Princeton University Press

Citation: This empirically rich work uses a myriad of data and unique data sets to explain the policy preferences and electoral choices of American voters. White Backlash also raises important twenty-first century questions pertaining to white American fears about immigration. Abrajano and Hajnal present sound theoretical arguments as to how immigration influences white Americans' core political identities and partisan change from the Democratic to Republican Party. One of the greatest contributions of this book is its use for political science scholars as well as policy practitioners, and Abrajano and Hajnal's findings have implications for changing race relations, coalitions, and future elections. Additionally, they find that increased racial and ethnic diversity is the contributing factor in the increased racial divides in American politics. On the cusp of one of the most important presidential elections in our nation's history, White Backlash is timely and essential to understanding the electoral choices of diverse groups in the American electorate.

\section{GLADYS M. KAMMERER AWARD}

The Gladys M. Kammerer Award is given annually for the best book published during the previous calendar year in the field of U.S. national policy.

Award Committee: Eleanor Powell, University of Wisconsin-Madison; Sarah Anzia, University of California, Berkeley; Andrew Rudalevige, Bowdoin College

Recipients: Helen Milner, Princeton University and Dustin Tingley, Harvard University

Title: Sailing the Water's Edge: The Domestic Politics of American Foreign Policy, Princeton University Press

Citation: Sailing the Water's Edge: The Domestic Politics of American Foreign Policy, Helen V. Milner and Dustin Tingley's pathbreaking new book, provides a fresh approach and answer to the question of how-and what kind of-foreign policy is made in the United States. In one sense, the answer is simple: "Domestic politics affects elements of foreign policy and does so differentially." But in showing that is so, and how it has worked in practice over three decades and more, the authors provide a stunning breadth of data and cutting-edge methods to provide convincing evidence that contradicts the old adage that politics stops at the water's edge.

The book is a tour de force that bridges numerous fields in political science too often studied in isolation. Milner and Tingley's unusual integration of theory, data, and methodological approaches from American politics, international political economy, and international relations pays substantial dividends for our understanding of the complexities of American foreign policy. Moreover, their sophisticated approach to the policy-making process unifies often disparate subfields within American politics including the presidency, public opinion, legislative politics, lobbying and interest group politics, organizational behavior, and foreign policy studies into an unusually cohesive whole.

Milner and Tingley succeed in bridging not just the water's edge but much of the open ocean between the policymaking literature across multiple subfields. Such an integrative effort is rarely attempted on this scale-and even more rarely achieved as successfully.

\section{VICTORIA SCHUCK AWARD}

The Victoria Schuck Award is given annually for the best book published on women and politics.
Award Committee: Jill Vickers, Carleton University, Chair; Fiona Mackay, University of Edinburgh; Shauna Shames, Rutgers University, Camden

Recipient: Sarah Deer, Mitchell Hamline School of Law

Title: The Beginning and End of Rape: Confronting Sexual Violence in Native America, University of Minnesota Press

Citation: This path-breaking book changes the women and politics field. It begins with the apparently simple question of why the rate of rape for Native girls and women is so much higher than for their non-Native counterparts but unlike other criminal acts occurs largely between the races. Deer maintains that America's post-colonial governments, her focus, both fail to protect Native girls and women but also largely prevent tribal courts from protecting them. Deer's work combines rich empirical detail, including searing personal testimonies, with forensic argument, and its thesis strikes at heart of the intersection of gender, race, and politics. She also carefully addresses her own positionality and evidence, which she discusses thoughtfully and convincingly. While feminists have for decades recognized and argued that rape is about power, Deer goes further by showing how it is enmeshed with colonialism and governance. Despite her focus on the US and its history, Deer's insights also apply to the many other settler societies in which colonialism oppressed and exploited Indigenous peoples. The "women and politics" field will be profoundly challenged by Deer's remarkable book and her contention that rape must be understood as an enduring violence that spans many generations and an injustice that echoes down the centuries as part of an unresolved trauma of colonization.

\section{WOODROW WILSON FOUNDATION} AWARD

The Woodrow Wilson Award is given annually for the best book on government, politics, or international affairs. The award, formerly supported by the Woodrow Wilson Foundation, is sponsored by Princeton University.

Award Committee: John Mollenkopf, City University of New York, Chair; James Robinson, University of Chicago; Ashutosh Varshney, Brown University

Recipient: Prerna Singh, Brown University Title: How Solidarity Works for Welfare: Subnationalism and Social Development in India 
Citation: Social scientists have been theorizing about the causes of social development at least since the 18 th century. Yet a vast amount of variation remains to be explained. In recent decades we have moved away from explanations based purely economic factors to consider a rich array of political, institution and society based determinants of development. In this context, Prerna Singh's book How Solidarity Works for Welfare: Subnationalism and Social Development in India, which received the Woodrow Wilson Prize in 2016, presents a radically new and original argument. Focusing on variation in social development outcomes within Indian states, and using an innovative mix of quantitative and qualitative methods, the book argues that it is differences in the emergence of sub-national identities that can explain variation in prodevelopment policy and thus social development. The book provides a historically rooted argument about the comparative emergence of sub-national identities in different regions of India and a rich set of ideas about how this can impact social policies and development through the behavior of both elites and citizens. It provides powerful and novel ideas about how to think about policy and promises to have the same sort of impact on political science that Robert Putnam's book, Making Democracy Work, has had.

\section{ROBERT A. DAHL AWARD}

The Robert A. Dahl Award is awarded annually to an untenured scholar who has produced scholarship of the highest quality on the subject of democracy. Scholarship eligible for the Dahl Award includes books, papers, and articles and reports on the subject of democracy.

Award Committee: Nadia Urbinati, Columbia University (Chair) and Todd Swanstrom, University of Missouri, St. Louis

Recipient: Lee Drutman, Senior Fellow, Political Reform Program, New America

The Business of America is Lobbying: How Corporations Became Politicized and Politics Became More Corporate, Oxford University Press 2016

Citation: Drutman changes the way we think about the role of business in American politics and the nature of lobbying. Lobbying, Drutman argues, is "sticky": lobbying causes more lobbying. Lobbyists push particular provisions to benefit the company that hired them. As legislation becomes more complex, Congress becomes more dependent on lobbyists to understand it. Seeing success, corporations spend more on lobbying.
Instead of countervailing power, corporations overwhelm the opposition-spending $\$ 34$ for every dollar spent by unions and public interest groups. The status quo becomes entrenched, favoring corporations and the wealthy. Both scholars and reformers will be forced to come to grips with Drutman's timely and disturbing analysis of business power in America.

\section{Dissertation Awards}

\section{GABRIEL A. ALMOND AWARD}

The Gabriel A. Almond Award is given annually for the best dissertation in the field of comparative politics.

Award Committee: Arthur Spirling, New York University, Chair; Lisa Blaydes, Stanford University; Marc Howard, Georgetown University

\section{Recipient: Dawn Teele, Yale University}

Title: “The Logic of Women's Enfranchisement: A Comparative Study of the United States, France and the United Kingdom"

Citation: Dawn Teele has written a superb dissertation in "The Logic of Women's Enfranchisement: A Comparative Study of the United States, France, and the United Kingdom." At the core of this work is an innovative theory that women won enfranchisement not primarily as a product of ideological change, but as the consequence of pragmatic, sometimes cynical, vote-winning strategies by office-seeking political parties. Thus, we can now understand why left- and right-wing parties both embraced, and at other times both rejected, suffrage expansion. Teele marshals impressive amounts of qualitative and quantitative evidence to demonstrate the plausibility of her case. The committee anticipates that this work, which contributes to the study of democratization, representation, and system change, will make for an important book of relevance right across the discipline.

\section{WILLIAM ANDERSON AWARD}

The William Anderson Award is given annually for the best dissertation in the general field of federalism or intergovernmental relations and state and local politics.

Committee: Liesbet Hooghe, University of North Carolina at Chapel Hill, Chair; Yoshiko Herrera, University of Wisconsin, Madison; Shanna Rose, Claremont McKenna College

Recipient: Philip Rocco, University of California, Berkeley
Title: "Reorganizing the Activist State: Conservatives, Commissions, and the Politics of Federalism, 1947-1996"

Citation: "Reorganizing the Activist State" stands out in that it addresses a big and contentious topic, develops an original theoretical explanation for why conservatives could advance limited government in intergovernmental relations, and examines the veracity of this and alternative explanations through a rigorous and intelligent use of plentiful archival evidence.

The dissertation examines the origins of conservative efforts to reform the New Deal era "activist state." It argues that institutional creativity, or more precisely, the creation and manipulation of institutions geared to fact collection and deliberation rather than binding authority-regenerative institutions-was decisive in weakening the activist state. These institutions helped reframe conservative objections from ideological to administrative criticism, broaden the coalition for change to a bipartisan clientele of local and state officials, and develop alternative limited government policy.

The study provides a corrective on extant work on American political development, which emphasizes the role of drift, conversion, and layering of existing authoritative institutions in gradual policy change. In contrast, this dissertation argues that the drivers of change can be external and weak: even in an environment saturated with powerful institutions, new institutions can provide an operating base for status quo challengers to the extent that they can store information, brokerage, expertise that can be mobilized to time an attack on prevailing policy.

\section{EDWARD S, CORWIN AWARD}

The Edward S. Corwin Award is given annually for the best dissertation in the field of public law.

Award Committee: Amy Steigerwalt, Georgia State University, Chair; Gretchen Helmke, University of Rochester; Anthony Lang, University of St Andrews

Recipient: Jud Mathews, Yale University

Title: "Constitutional Rights, Private Law, and Judicial Power"

Citation:Jud Mathews of Yale University offers a theoretically rich and empirically engaging answer to the question of constitutional doctrinal dispersion. Mathews offers a novel theory of when such horizontal rights expansion may occur, arguing that courts apply such arguments when there is a "normative gap" in the protection of 
individual rights in these private interactions that can be potentially filled through the application of constitutional rights. However, Mathews further argues that this gap is necessary but not sufficient: since courts and judges are political actors, expansion is also predicated on the fulfillment of judicial interests, whether ideological, institutional or something else entirely.

Mathews offers a theory which takes into account the political, historical, doctrinal, and institutional aspects of judicial decision-making. By adopting a historical/ developmental account, Mathews's analysis differs from previous comparative studies, moving us beyond a simple legal analysis of doctrinal development. Ultimately, he provides an argument for how high courts' application of horizontal rights impacts the wider constitutional discourse in all three countries and the potential effects when courts doand do not-engage in such rights analysis expansion.

\section{HAROLD D, LASSWELL AWARD}

The Harold D. Lasswell prize is awarded annually for the best dissertation in the field of public policy. The award is co-sponsored by the Policy Studies Organization.

Award Committee: Jennifer Clark, University of Houston, Chair; Christian Breunig, University of Konstanz; Chris Koski, Reed College

Recipient: Brian Palmer-Rubin, University of California, Berkeley

Title: "Evading the Patronage Trap: Interest Organizations and Policymaking in Mexico"

Citation: The committee has unanimously selected "Evading the Patronage Trap: Interest Organizations and Policymaking in Mexico" as the recipient of the Harold Lasswell Award. In this study, Palmer-Rubin calls for a return to the study of organizations representing collective interests and their effect on policymaking. He departs from the prevailing research linking poverty to demand for patronage, arguing that membership conditions and electoral competition can overtake class pressure and provide a pathway for organizations to influence policymaking. Through case studies and data on the distribution of subsidies across 32 Mexican states, Palmer-Rubin builds a compelling argument for the role of organizations in the policymaking process. This important study should generate considerable attention among comparativists and interest group scholars alike.

\section{HELEN DWIGHT REID AWARD}

The Helen Dwight Reid Award is given annually for the best dissertation successfully defended during the previous two years in the field of international relations, law, and politics.

Award Committee: Kristian Skrede Gleditsch, University of Essex, Chair; Susan Hyde, Yale University; Paul Poast, University of Chicago

Recipient: Melissa Lee, Stanford University Title: "Mind the Gap? The International Sources of Sovereignty and State Weakness"

Citation: Lee's dissertation emphasizes how "bad neighborhoods" and hostile neighbors can explain divergences of gaps between formal sovereignty and effective statehood. It provides a novel theoretical approach to an important problem, demonstrated by the large differences in effective sovereignty and state strength in many territories, and highlights the important geopolitical context of domestic conflict and state failure. The thesis develops an innovative approach to measuring the notoriously difficult concept of state capacity, based on variation in the quality of demographic data. It combines insights from strong research designs at different geographical scales, including comparative sub-national analysis, a quasi-experiment on the effects of Thailand of the Vietnamese invasion of Cambodia, and archival material from Malaysia and the Philippines.

\section{E.E. SCHATT SCHNEIDER AWARD}

The E.E. Schattschneider Award is given annually for the best doctoral dissertation completed and accepted during that year or the previous year in the field of American government.

Award Committee: Lina Newton, Hunter College, Chair; Dan Hopkins, Georgetown University; Kent Portney, Texas A\&M University

\section{Recipient: Rachel Potter, University of Michigan}

Title: "Writing the Rules of the Game: The Strategic Logic of Agency Rulemaking"

Citation: Rachel Potter's dissertation takes on an important component of federal policymaking that is often ignored and yet central to the notion of democratic accountability: the practice of "notice-and-comment" rulemaking. At the outset, Potter notes that agencies are quite successful at having their preferred rules survive veto by the Office of Information and Regulatory Affairs (OIRA). The rest of the project explains why "notice-and-comment," which should open rulemaking to political oversight, instead is vulnerable to bureaucratic control.

The committee was impressed with the originality and the scope of the project, which bridges scholarship in political science and public administration. Potter develops a theoretical model, tests that model against regulatory data from OIRA spanning multiple years and agencies, then further develops the practical implications of her argument using interviews with bureaucrats as well as a case study. Ultimately, the research supports a unique argument that questions the value of institutional mechanisms designed to impose political control on agencies.

\section{LEO STRAUSS AWARD}

The Leo Strauss Award is given annually for the best dissertation in the field of political philosophy.

Award Committee: Jill Hargis, California State Polytechnic University, Pomona, Chair; Leigh Jenco, London School of Economics; Lars Tønder, University of Copenhagen

\section{Recipient: Matthew Longo, Yale University}

Title: "Sovereignty in the Age of Securitization: A Study on Borders and Bordering in the United States after 9/11"

Citation: Matthew Longo takes up a familiar phenomenon-the crossing of a border filled with hopes and anxiety-and turns it into a thought-provoking exploration of the border as a liminal zone in which politics is made. Moving beyond understandings of borders as lines of demarcation, he argues that they are thick, multifaceted, and bi-national institutions with their own histories and logics. Using a combination of sophisticated theoretical material and original empirical evidence, Longo argues that countries have moved to a mode of "co-bordering", in which states cede sovereignty for security. The potential harm is a "neo-Imperial overreach" that moves international politics from a situation of heterarchy back to a mode of hierarchy. The dissertation will most certainly be agenda-setting for debates about sovereignty, migration, justice, and democracy.

\section{LEONARD WHITE AWARD}

The Leonard D. White prize is awarded annually for the best dissertation successfully defended during the previous two years in the field of public administration.

Award Committee: Rosemary O'Leary, University of Kansas, Chair; Sergio Fernandez, Indiana University; Susan Miller, University of South Carolina 
Recipient: Bruce Jones, University of Texas at Dallas

Title: "An fMRI Study of the Reward Preferences of Government and Business Leaders"

Citation: The committee unanimously chose the dissertation "An fMRI Study of the Reward Preferences of Government and Business Leaders." This research furthers public service motivation theory through a creative study that used neuroimaging of the brains of government and business leaders to answer two research questions: 1) Do the reward preferences between government and business leaders reveal themselves at the neural level in the brain? 2) Do these responses to monetary rewards differ significantly between government and business leaders? Both questions were answered in the affirmative. The behavioral and neural data of this study provide preliminary evidence that there may be a biological basis to the divergent reward preferences of business and government leaders published in previous literature.

\section{Paper and Article Awards}

\section{FRANKLIN L. BURDETTE/PI SIGMA ALPHA AWARD}

The Franklin L. Burdette/Pi Sigma Alpha Award is given annually for the best paper presented at the previous year's annual meeting. The award is supported by Pi Sigma Alpha.

Award Committee: Carol Nackenoff, Swarthmore College, Chair; Jake Bowers, University of Illinois; Jonas Pontusson, University of Geneva

Recipients: John Voorheis, University of Oregon; Nolan McCarty, Princeton University; Boris Shor, Georgetown University

Title: "Unequal Incomes, Ideology and Gridlock: How Rising Inequality Increases Political Polarization"

Citation: Rising income inequality and its political consequences are important topics of major concern across political science. In an extensive investigation of American state legislatures and legislators from 1993 to 2013, Voorheis, McCarty, and Shor demonstrate a causal link between increasing inequality and partisan polarization at the state level. The authors amend conventional wisdom, demonstrating that inequality moves state legislatures to the right, displacing moderate Democrats with Republicans and leaving Democrats more liberal. Within-district inequality moves Republicans to the right while between-district inequality moves Democrats to the left. The authors argue persuasively that polarization begets more inequality over time, as Republicandominated legislatures are unlikely to enact redistributive policies and polarization increases legislative gridlock.

\section{Recipient: Pablo Barberá, New York University}

Title: "How Social Media Reduces Mass Political Polarization: Evidence from Germany, Spain, and the U.S."

Citation: Social network sites are important places where citizens consume political information. In this innovative and elegant paper, Barberá counters the prevailing view that social media networks function as echo chambers to produce more extreme, polarized political opinions. Examining individuals using Twitter accounts in Spain, Germany, and the United States, Barberá constructs a dynamic measure of the political ideology of Twitter users based on who they follow. His analysis shows that users joined by weak ties are incidentally exposed to diverse political opinions and become more moderate over time. Barberá also presents survey evidence from the same three countries to support this conclusion, and uses voter records from five US states to match Twitter profiles with evidence of offline behavior.

\section{HEINZ EULAU AWARD: APSR}

The Heinz Eulau Award is given annually for the best article published in the American Political Science Review in the past calendar year. The award is supported by Cambridge University Press.

Award Committee: Aseem Prakash, University of Washington, Chair; Michelle Dion, McMaster University; Martin Gilens, Princeton University

Recipients: Ariel White, Harvard University; Noah Nathan, Harvard University; Julie Faller, Harvard University

Title: "What Do I Need to Vote? Bureaucratic Discretion and Discrimination by Local Election Officials"

Citation: White, Nathan, and Faller examine an important contemporary political issue: voter identification (ID) laws that have emerged in 31 states. Because many citizens do not know if they need IDs to vote, or what type of IDs are required, they ask local officials for help. Using a field experiment involving 7,00o election officials in 48 states, the paper examines whether local election administrators discriminate in the information they provide to voters. In their experiment, the authors e-mailed local officials asking either what ID would be needed in the upcoming election, or whether the citizen was required to vote in the primary election in order to vote in the general election.

The paper finds that officials discriminate on the basis of ethnicity: administrators are less likely to respond to emails sent from Latino aliases as opposed to non-Latino white aliases. Further, responses to Latino aliases are of lower quality. The paper highlights the issue of racial profiling by local officials and how this leads to systematic bias against minority citizens who wish to exercise their franchise. The committee was impressed by the substantive issue of enquiry, which has far reaching implications for the study of democracy and equity.

\section{HEINZ EULAU AWARD:}

\section{PERSPECTIVES}

The Heinz Eulau award is given annually for the best article published in Perspectives on Politics in the past calendar year. The award is supported by Cambridge University Press.

Award Committee: Aseem Prakash, University of Washington, Chair; Virginie Guiraudon, Sciences Po; Macartan Humphreys, Columbia University

Recipient: Rebecca Thorpe, University of Washington

Title: "Perverse Politics: The Persistence of Mass Imprisonment in the Twenty-first Century"

Citation:Rebecca Thorpe's article, "Perverse Politics: The Persistence of Mass Imprisonment in the Twenty-first Century", examines the political economy of mass incarceration. Thorpe argues that the economic interests of poor, rural areas interact with incarceration policies to create policy lock-in. Her careful empirical analysis suggests that prisons are located in poor rural areas because of the economic benefits they bring and that by providing a stable source of employment to rural and predominantly white communities, prisons play a distributive function that will make the carceral system resistant to reform. Thorpe's study brings original data to examine a novel argument of importance to the scholarly and policy debate. Though focused on the US, the argument is general in nature and is likely to resonate well beyond the US context. 